Portland State University

PDXScholar

Engineering and Technology Management

Faculty Publications and Presentations

\title{
The Effectiveness of Entrepreneurship Programs to Reduce Unemployment in Developing Countries: The Case of Saudi Arabia
}

\author{
Dana Bakry \\ Portland State University \\ Rafaa Ibrahim Khalifa \\ Portland State University, rafaa.khalifa@gmail.com \\ Maoloud Dabab \\ Portland State University
}

Follow this and additional works at: https://pdxscholar.library.pdx.edu/etm_fac

\section{Let us know how access to this document benefits you.}

\section{Citation Details}

D. Bakry, R. Khalifa and M. Dabab, "The Effectiveness of Entrepreneurship Programs to Reduce Unemployment in Developing Countries: The Case of Saudi Arabia," 2019 Portland International Conference on Management of Engineering and Technology (PICMET), Portland, OR, USA, 2019, pp. 1-8.

This Article is brought to you for free and open access. It has been accepted for inclusion in Engineering and Technology Management Faculty Publications and Presentations by an authorized administrator of PDXScholar. Please contact us if we can make this document more accessible: pdxscholar@pdx.edu. 


\title{
The Effectiveness of Entrepreneurship Programs to Reduce Unemployment in Developing Countries: The Case of Saudi Arabia
}

\author{
Dana Bakry, Rafaa Khalifa, Maoloud Dabab \\ Dept. of Engineering and Technology Management, Portland State University, Portland, OR - USA
}

\begin{abstract}
Starting a new business, developing new products and/or services and bringing those to the market may seem deceitfully easy, but in reality, it is a very painful and risky endeavor that can be nearly impossible to undertake without proper implementation process in place. Several entrepreneurship programs have been established in different regions or countries to make a positive economic change while remaining profitable for both people and the government. Saudi Arabia is a rich country that enjoys high financial potential. In spite of the country is taking remarkable steps into the entrepreneurship world, there are still unique challenges that inspire or hamper entrepreneurs to engage in the entrepreneur programs' process more fully. In this paper, we explored these challenges and show the transformation of the ecosystem strategy that the Saudi Arabia government has taken to develop the entrepreneurship ecosystem and startup. The study aims to investigate and analyze the relationships between the effectiveness of entrepreneurship programs and unemployment. The paper, however, concludes that the existing entrepreneurship ecosystem is still needed development in order to resolve the problem of unemployment in Saudi Arabia. The country should improve the strategies that can support to create an entrepreneurial culture and encourage the youth to involve in starting new enterprises.
\end{abstract}

\section{INTRODUCTION}

Nowadays, unemployment is one of the most pressing challenges facing the government of the Kingdom of Saudi Arabia [1]. At the same time, entrepreneurship is being brought to the forefront of the Saudi government strategic economic planning. Entrepreneurship is very important for economic growth and development [2][3][4]. Saudi's government is supporting and facilitating many further entrepreneurial growths, and it is focusing on how to grow entrepreneurship contribution to the economy. The Saudi government focuses on innovation and entrepreneurship to solve the economic challenges by increasing the rate of unemployment which is usually associated with the lack of self-employment [5]. The Kingdom of Saudi Arabia implements two employment creation strategies [1]. The first strategy is to combine the unemployment issue through direct self-employment. The second is to get more benefit from entrepreneurial activities in creating more jobs for other unemployed. Before 10 years ago, according to Global Entrepreneurship Monitor (GEM) survey, Saudi Arabia had the lowest total entrepreneurial activity (TEA) rate, only $4.7 \%$ of the adult population (18-64 years old) were actively involved in the start-up of a new business or owned a young business of less than three and half years old [6].

The topic is important because Saudi Arabia raises the alarm over rising unemployment. On the other hand, it is hard for both the public and private sectors to be staffed by all the youth graduates. Therefore, since early of this decade, Saudi Arabia has attracted the populations' attention through creating enterprises instead of depending on the oil sector. However, there are policies and regulatory improvements that still need to take place in order for these enterprises to be widespread in the market [7].

Today, most of the countries have turned on the importance of entrepreneurship. Entrepreneurship has an impact on economy execution. It becomes an effective component of the economic power of the countries. Entrepreneurship is launching a small business with the ability to develop and manage it along with any of its risks to make a revenue. There are always offensive factors that can be one of them or their combination for closing the start-up businesses. These factors can be related to the area of policies, finance, culture, human capital, or market [7]. The most critical factors are lack of funding, economic crisis, and decision-making mistakes in business. Also, low education levels can be a significant factor that prevents people from becoming entrepreneurial business owners, as many rural schools have lack of proper teachers and resources [8]. Education is an important factor for the most successful entrepreneurs [9]. The Kingdom of Saudi Arabia is categorized as a high-income country by the World Bank's income groups [10]. Mostly, in this category, entrepreneurs focus on increasing income more than choosing entrepreneurship to achieve independence [9].

Recently, the Saudi Arabia government sponsor the field of technology transfer, innovation, and entrepreneurship because of its effect on its knowledge economy. The government can use this knowledge for decision support systems to produce economic value in many different fields. This research shows the status of the entrepreneurship ecosystem in Saudi Arabia, and how the government supports entrepreneurship and the private sector to lead role in economic development through job creation and competitiveness. The paper focuses on entrepreneurship because for purposes of efficiency, and how it is appointed to reduce Unemployment in Saudi Arabia. Our main purpose of the research to explore challenges that inspire or hamper entrepreneurs to engage in the entrepreneur 
TABLE I. UNEMPLOYMENT STATUS IN SAUDI ARABIA - WORLD BANK 2018 [16]

\begin{tabular}{|c|c|c|c|c|c|c|c|}
\hline Saudi Arabia - 11/14/2018 & \multicolumn{7}{|c|}{ World Development Indicators (2011 - 2017) } \\
\hline Indicator Name & 2011 & 2012 & 2013 & 2014 & 2015 & 2016 & 2017 \\
\hline Labor force, total & 10487696 & 11202506 & 11845700 & 12391396 & 12991603 & 13431362 & 13834229 \\
\hline Unemployment, total (\% of total labor force) & 5.769999 & 5.621799 & 5.5700001 & 5.8766999 & 5.5900001 & 5.6500001 & 5.8899998 \\
\hline Unemployment, male (\% of male labor force) & 3.349999 & 2.923799 & 2.7799999 & 2.8636999 & 2.4400000 & 2.5099999 & 3.2237000 \\
\hline $\begin{array}{l}\text { Unemployment, female (\% of female labor } \\
\text { force) }\end{array}$ & 19.20999 & 20.53790 & 20.729999 & 21.957000 & 21.379999 & 21.100000 & 21.298400 \\
\hline $\begin{array}{l}\text { Unemployment, youth total (\% of total labor } \\
\text { force ages } 15-24)\end{array}$ & 28.77099 & 27.83699 & 28.965000 & 30.122999 & 28.97599 & 24.87199 & 25.02099 \\
\hline
\end{tabular}

programs' process more fully. Also, to investigate the relationships between the components of the existing entrepreneurship ecosystem in order to find its impact on the unemployment issue in the Kingdom of Saudi Arabia.

\section{RESEARCH METHOdOLOGY}

This study focused on a literature review. It reviews the theoretical aspects of research that have done in the area of entrepreneurship programs and unemployment. A case-study approach was adopted. The Kingdom of Saudi Arabia country was chosen to explore the effectiveness of its entrepreneurship ecosystem for reducing the unemployment issue. The investigation was depended on the historical literature published in the entrepreneurship and unemployment area. Also, in this paper the data was collected from two main sources: The Global Entrepreneurship Monitor (GEM) survey and the World Bank report, 2017 - 2018. Besides, the experience of the authors in the region and the field of entrepreneurship was used to validate the valuable data from the research analysis results.

\section{UNEMPLOYMENT}

One of the economic problems is unemployment, and it becomes more serious when the rate of unemployment rises among young people. Unemployment means people want to have a job as a source of income and satisfy their needs, but they cannot find a suitable job. Increasing the unemployment rate in an economic system causes destitution, hunger, and frustration [11]. Some economists classify unemployment into hardcore unemployment, seasonal unemployment, and hidden unemployment. Fundamentally, unemployment can be the incorporation of different kinds [4]. Unemployment can emerge for different reasons. They could be different between countries. For example, a weak education system, the lack of adequate educational infrastructure and vocational education in Russian regions cause youth unemployment. Social factors have also been associated with unemployment subject [12]. The rate of unemployment is noticeably high in the global youth generation illustrating about 75 million youth are without a job [13]. However, unemployment is a common issue in all regions around the world [14]. In Saudi Arabia (Vision 2030) the rate of unemployment is $11.6 \%$, and One of the top priorities in the kingdom's national development plan is having women's participation in the labor market [15]. The Saudi government focuses on boosting SMEs as essential agents of economic development in order to replace the traditional reliance on oil with the creation of a dynamic private sector generating jobs for the young population. As shown in Table .1, the total labor force was increased by $21.4 \%$ in 2017 compared with the indicator in 2011. The total unemployment rate is indicated to an average of $5.7 \%$ between 2011 and 2017 . The unemployment rate for adult indicates to $3.22 \%$ of male labor force in 2017 , while the unemployment rate for female indicates to $21.29 \%$ in the same year. The unemployment rate for youth total (\% of total labor force ages $15-24$ ) declined from $28.77 \%$ in 2011 to $25.02 \%$ in 2017 [16].

It is important to consider the factors on the demand side and the supply side in the economy [17]. Kongolo mentions that it is important to qualify young people to involve in starting small businesses by training them on management skills and using technologies. Also, one of the significant reasons for having unemployment in a country is less number of vacancies [18]. In Saudi Arabia is about $51 \%$ of the population are under the age of 25, and the highest percentage of Saudi job-seekers is in the age group 25-29 years [19]. Half of the Saudi job-seekers are university graduates [16]. Unemployment has consequences that make governments fret. Unemployment does not produce social disgruntlement only, and it can also create a negative effect on businesses and the economic health of the country especially with very long lasting of unemployment. In VISION 2030, Saudi's government promised to provide opportunities for everyone - men and women, young and old. The government is seeking to make the most of the potential of the country workforce by encouraging a culture of high performance. These efforts aim to create new jobs and enterprises. The Kingdom of Saudi Arabia continues to lower the rate of unemployment from $11.6 \%$ to $7 \%$ by 2030 [15]. 


\section{LITERATURE REVIEW}

The entrepreneurship can be a response to previously undiscovered opportunities. There have been significant efforts and many strategies implemented to boost employment through the Entrepreneurship programs [20]. For instance, a study established a connection between entrepreneurship and reducing unemployment by creating the culture of job creation with the youths think [21]. The high rate of unemployment might be associated with a low degree of self-employment [22].

\section{A. Antecedents Of Entrepreneurship}

Zimmerman states that "Entrepreneurship is the recognition or creation of an opportunity, coupled with action by an individual or group of individuals, to form a social, entrepreneurial, lifestyle, middle-market, or highly-liquid venture" [23]. Furthermore, entrepreneurship introduces new products and services in order to attempt to transform innovations into monetary value [24]. In the economic world, an entrepreneur is a person who can find opportunities to translate inventions or technology into new products that are a commercially viable innovation [25]. To raise the number of entrepreneurs in a country, we need to create an environment that promotes to produce an entrepreneur. That means we need to have an entrepreneurial culture.

Culture means a social behavior [26] that transmitted through social learning in human societies. It is one of the most valuable things that a country has and some aspects of social behavior such as art, cooking, technologies, and so on. Create or build culture is not something easy to do, but it can change the take the country to a better position and give this country a trait. Creating an entrepreneurial culture needs an environment that supports and motivates the individual to innovate and take risks. For example, Silicon Valley, in San Francisco, is a famous place for startup technology companies. There are important contributing factors that help this valley to grow and succeed such as a skilled STEM research base housed in area universities, sufficient venture capital, and Stanford University leadership [27]. There some studies talk about how culture has an impact and important role on institutions and economic performance [28][29].

In order to spread the culture of entrepreneurship, there are antecedents of entrepreneurship. First, it is essential to prepare human resources and develop them. Entrepreneurs should have management skills in order to transact with all functions of management, planning, organizing, staffing, directing, coordination, reporting \& budgeting. There are no many studies that mention how necessary are the skills of functions of management for the entrepreneur. It may seem as an axiom and doesn't need to be mentioned. However, from the point of view, the skills of functions of management for entrepreneurs should be mentioned even before talking about funding and financial issues. Healthy management is the basis of the success and sustainability of an enterprise. Management is a social procedure that is participating responsibility for economic and effective planning \& organization of operation of an enterprise in the fulfillment of given purposes [30]. Modern management needs to incorporate technology into businesses [31]. For this reason, the entrepreneur needs to have adequate knowledge of utilizing technology. For example, the entrepreneur needs to use technology to conduct primary research in addition to applying online surveys and customer feedback.

Furthermore, in order to consolidate the concept of entrepreneurship among young people, we need to spread the culture of entrepreneurship and build innovation entrepreneurship in universities. Through entrepreneurship education, young people learn skills that are transferable skills sought by employers, for example, interpersonal skills, time management, and leadership development [32]. As entrepreneurship is a part of the economic development strategy that countries utilize to achieve economic benefits, governments need to regulate and improve the conditions of enterprises with supportive, implementation and funding policies. For example, business incubators can be made available by a responsive government to fill gaps that have been identified in entrepreneurship support activities.

One of the most essential purposes of business incubators is economic development. Some developing countries have invested their resources in order to set up policies that intended to uplift entrepreneurship such as China, Brazil, Saudi Arabia. In Brazil, entrepreneurship has improved very fast because of government policies. The government has helped to develop low-tech businesses as well as high technology-oriented companies [33]. Also, they are concerted efforts have been made by the Chinese government through policies and resources on the development of high technology businesses [34]. We will talk later about the role of the Saudi Arabia government to simplify administrative frameworks and reducing barriers for entrepreneurs.

\section{B. The Relationship Between Entrepreneurship And Unemployment}

There is a practical alternative for unemployed people to find a source of their income or for people who work with a low salary. They can find or increase their income by transferring their orientation into self-employment or entrepreneurship. Startup business activities will be increased because of the decreasing opportunity cost. Decreasing the opportunity cost is a result of the increased unemployment rate [22]. Researchers have measured and tested the opportunities that are come from entrepreneurship to the individual [35]. Faria et al. state that the rate of unemployment influences the rate of entrepreneurship. They implement a granger-causality test on data from Australia, Germany, the United Kingdom, and the United States, as developed countries [36]. Oladele et al. use a multiple regression model on data in order to investigate the necessity of promoting employment in Nigeria. The aim of their study is trying to find the relation between unemployment and entrepreneurship [37].

Although their study suggests a supporting idea regarding the importance of establishing new entrepreneurship programs, they did not prove the role of reducing the rate of unemployment by entrepreneurship. According to Catherine et al., "Many countries are turning to active labor market programs (ALMP) to increase individuals' incentive to start a business and to reduce unemployment. For example, in Finland, start-up 
incentives appear as a one-off grant of $€ 32.66$ per day for entrepreneurs with a feasible business plan. The aim of the startup grants paid on a monthly basis is to replace unemployment benefits for unemployed people."[38] However, there are some studies mention that increasing the unemployment level correlates with decreasing economic growth. This connection may drive to minimize the number of entrepreneurial opportunities [39]. Also, the low rate of entrepreneurship initiatives may produce low economic growth levels, which leads to increasing the rate of unemployment [22]. There is a collective agreement from researchers upon that entrepreneurship has a significant effect on the economic prosperity of individuals, regions, and nations. In the early evolution of production, entrepreneurs have an effective role in introducing new products or processes [40].

Moreover, in the long term, entrepreneurs have an impact on enhancing productivity through increased competition. The increasing numbers of entrepreneurs and effective innovation can help in economic growth [4]. Small businesses have a great position in the economy of developed countries. According to Kongolo, $91 \%$ of the formal business entities are small businesses in South Africa. They also share about 51 and 57\% of GDP and offer

almost $60 \%$ of employment [18]. Anokhin et al. have made the first attempt to introduce measures of innovative and technological arbitrage opportunities into the entrepreneurship literature to illustrate their possible use for future studies [41]. They outline how the DEA method and the Malmquist productivity index can be used to quantify macro-level opportunities for entrepreneurship in national economies. This methodology could be advantageous for studying the relationships between the two types of opportunities and ultimately their influence on new venture formation processes and economic development.

\section{The NATIONAL ENTREPRENEURIAL FrAmEWORK CONSTRAINTS AND SUPPORT}

Saudi Arabia released its Vision 2030 for national long-term economic growth in 2016 [42]. The vision aims to transform the state-led economy into a private sector. Some areas are already showing improvement such as the Kingdom's efforts for entrepreneurship development. In 2016 the government established and included the Saudi Entrepreneurship Authority objectives aligning with the national vision. Several policies and regulations have been developed and strengthened to protect investors and increase shareholder rights and more transparency overall.

Over the past decade, Saudi Arabia has made progress on the national market and improvements in technological readiness, education system, and infrastructure. However, the country is facing a huge challenge to create 6 million jobs by 2030 in the private sector [43].

Recently, a new entrepreneurial framework was developed and evaluated by the Saudi Arabian' Experts. As shown in table .2, the major improvement of 2017 was to the government programs condition. Five components of the entrepreneurial framework conditions showed increases. The commercial and physical infrastructure conditions showed the major weakening, where the averages for all components declined [7]. The assessment indicates education and training as the most critical condition that requires intensive and effective actions. However, all the entrepreneurial conditions are interrelated of a better framework for entrepreneurs, and the government seems to pay more attention to this subject.

TABLE II. AVERAGE SCORES FOR THE INDIVIDUAL COMPONENTS OF THE ENTREPRENEURIAL FRAMEWORK CONDITIONS IN SAUDI ARABIA-RECENT EVOLUTION, 2016-2017 [7]

\begin{tabular}{|c|c|c|c|c|}
\hline Government programs condition - Statement & $\begin{array}{c}2017 \\
\text { Average }\end{array}$ & $\begin{array}{c}2016 \\
\text { Average }\end{array}$ & $\begin{array}{l}\text { \% Change } \\
2017 / 2016\end{array}$ & Evolution Sign \\
\hline $\begin{array}{l}\text { "A wide range of government assistance for new and growing firms } \\
\text { can be obtained through contact with a single agency." }\end{array}$ & 2.83 & 2.62 & 8.02 & Positive \\
\hline $\begin{array}{l}\text { "Science parks and business incubators provide effective support } \\
\text { for new and growing firms." }\end{array}$ & 4.56 & 4.00 & 14.00 & Positive \\
\hline $\begin{array}{l}\text { "There is an adequate number of government programs for new } \\
\text { and growing businesses". }\end{array}$ & 4.33 & 4.33 & 0,00 & Equal \\
\hline $\begin{array}{l}\text { "The people working for government agencies are competent and } \\
\text { effective in supporting new and growing firms". }\end{array}$ & 3.45 & 3.10 & 11.29 & Positive \\
\hline $\begin{array}{l}\text { "Almost anyone who needs help from a government program for a } \\
\text { new or growing business can find what they need." }\end{array}$ & 3.08 & 2.87 & 7.32 & Positive \\
\hline $\begin{array}{l}\text { "Government programs aimed at supporting new and growing } \\
\text { firms are effective." }\end{array}$ & 4.03 & 3.51 & 14.81 & Positive \\
\hline
\end{tabular}


TABLE III. TOPICS CITED BY GEM EXPERTS AS THE MAIN CONSTRAINTS ON, AND SUPPORTS FOR, ENTREPRENEURSHIP IN SAUDI ARABIA, 2016 AND 2017 [7]

\begin{tabular}{|c|c|c|c|c|c|}
\hline \multirow{2}{*}{ Constraints - Topics Cited } & \multicolumn{2}{|c|}{$\begin{array}{c}\text { Percentage of Valid } \\
\text { Responses }\end{array}$} & \multirow[b]{2}{*}{ Support - Topics Cited } & \multicolumn{2}{|c|}{$\begin{array}{c}\text { Percentage of Valid } \\
\text { Responses }\end{array}$} \\
\hline & 2017 & 2016 & & 2017 & 2016 \\
\hline Financial support & 59.46 & 57.14 & Financial support & 25.71 & 14.29 \\
\hline Government policies & 70.27 & 65.71 & Government policies & 54.29 & 22.86 \\
\hline Education and training & 18.92 & 17.14 & Education and training & 22,86 & 17.14 \\
\hline R\&D transfer & 10.81 & 11.43 & R\&D transfer & 14.29 & 11.43 \\
\hline Commercial infrastructure & 10.81 & 14.29 & Commercial infrastructure & 8,57 & 17.14 \\
\hline Internal market openness & 8.11 & 5.71 & Internal market openness & 8.57 & 22.86 \\
\hline Physical infrastructure access & 2.70 & 5.71 & Physical infrastructure access & 14.29 & 14.29 \\
\hline Capacity for entrepreneurship & 21.62 & 5.71 & Capacity for entrepreneurship & 20.00 & 25.71 \\
\hline Economic climate & 8.11 & 2.86 & Economic climate & 8,57 & 11.43 \\
\hline Workforce features & 2.70 & 8.57 & Workforce features & 5.71 & 0.00 \\
\hline Perceived population composition & 0.00 & 0.00 & Perceived population composition & 2.86 & 14.29 \\
\hline Political, institutional and social context & 0.00 & 14.29 & Political, institutional and social context & 5.71 & 2.86 \\
\hline Economic crisis & 0.00 & 0.00 & Economic crisis & 0.00 & 0.00 \\
\hline Corruption & 0.00 & 0.00 & Corruption & 0.00 & 0.00 \\
\hline $\begin{array}{l}\text { Different performances of small, medium and } \\
\text { large companies }\end{array}$ & 2.70 & 5.71 & $\begin{array}{l}\text { Different performances of small, medium and } \\
\text { large companies }\end{array}$ & 0.00 & 2.86 \\
\hline Internationalization & 0.00 & 0.00 & Internationalization & 0.00 & 0.00 \\
\hline Labor costs, access, and regulation & 24.32 & 0.00 & Labor costs, access, and regulation & 0.00 & 0.00 \\
\hline Other, don't know & 0.00 & 0.00 & Other, don't know & 0.00 & 0.00 \\
\hline
\end{tabular}

In 2017, as shown in table .3, Ten out of 20 possible topics were analyzed and considered as constraints on entrepreneurship in Saudi Arabia [7]. These main topics were relating to:

- Government policies

- Financial support

- Labor costs

- Access and regulations

- The capacity for entrepreneurship

- Entrepreneurial education and training

- Cultural and social norms

- R\&D transfer

- Commercial infrastructure

- The economic climate

- Internal market openness

Government policies, financial support, education and training, culture and social norms, R\&D transfer, physical infrastructure, and government programs for entrepreneurs were also considered as supports for entrepreneurship. However, comparing with the fact that identified in 2016, the year of 2017 showed many genuinely positive actions that are going on in this field. Also, the economic climate was significantly indicated as a constraint and its decreasing identification as support.

The average status of Saudi Arabia's entrepreneurial framework conditions had a lower than average status of the GEM, and Asia entrepreneurial frameworks, except for internal market dynamics and social and cultural norms. The entrepreneurial education and $\mathrm{R} \& \mathrm{D}$ transfer were ranked as less important elements, while the highest importance elements were internal market dynamics, physical infrastructure, and government entrepreneurship programs.

\section{ENTREPRENEURSHIP ECOSYSTEM AND ACTORS INVOLVED}

The Kingdom of Saudi Arabia is the largest economy in the Middle East and North Africa region. More than $87 \%$ of its budget revenues come from the petroleum sector. The economy in Saudi Arabia has improved from the global oil price surge during the past decade [44]. In 2014, because of the worldwide decline in the oil price, economic revenues and fiscal surpluses had halted. 
Bolstering Entrepreneurship in Saudi Arabia

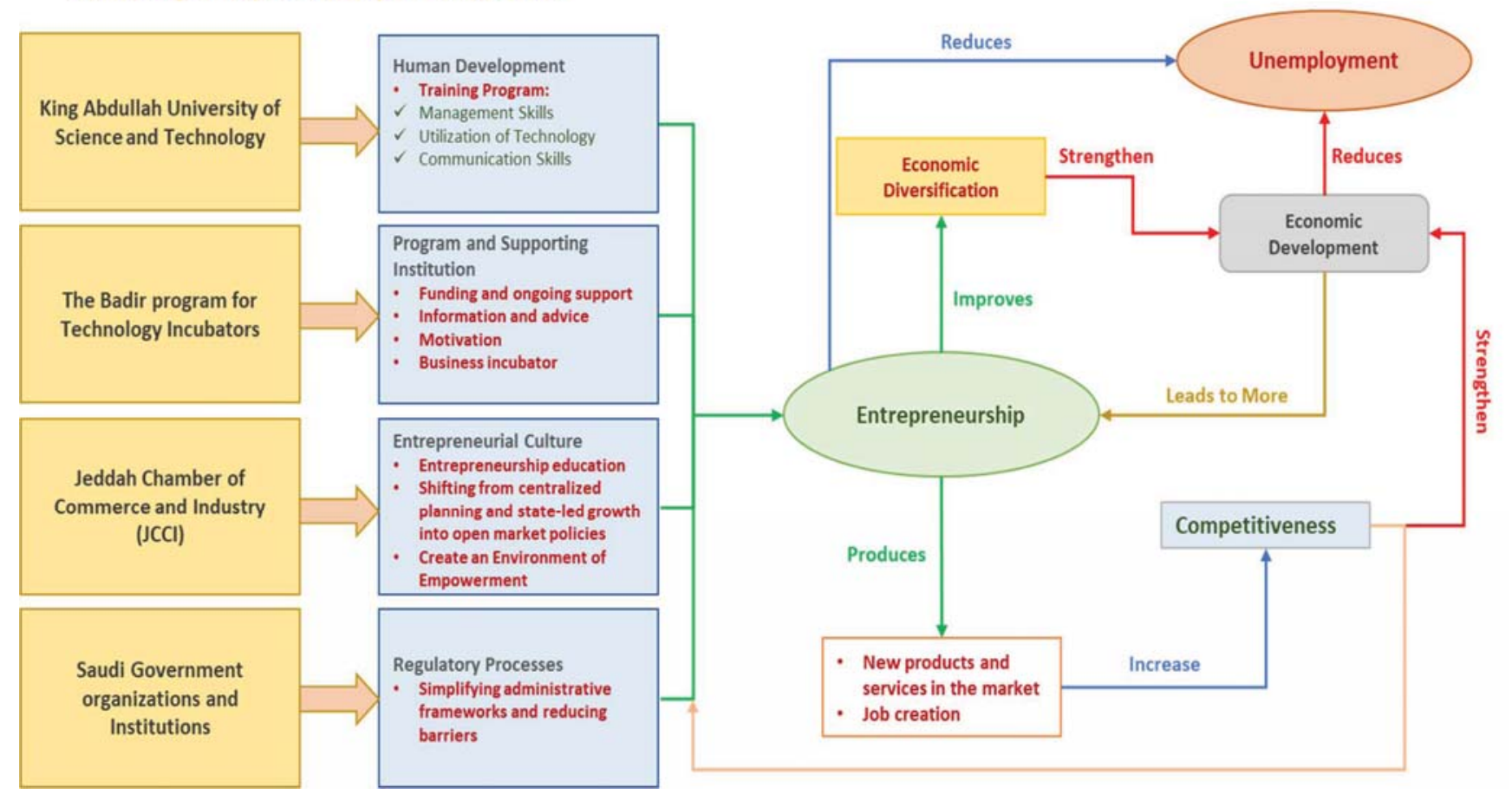

Fig. 1. Saudi Arabia Entrepreneurship Ecosystem

For this reason, the Saudi Arabia government has decided to strengthen its non-petroleum sectors in order to diversify its oildependent economy [45]. The Saudi Arabia government released an economic blueprint for national long-term economic growth in 2016. The objective of this plan is shifting from centralized planning and state-led growth into open market policies. That means entrepreneurship and the private sector can have a primary role in economic development through job creation and competitiveness [46]. As we know, substantial costs and complex registration processes can discourage entrepreneurial activity. For that, the Saudi government simplifies the administrative framework and reduces barriers to encourage business entrepreneurship (see Figure 1).

Now in Saudi Arabia, entrepreneurs can complete registration in one procedure within one day at the new one-stop shop in Riyadh. The one-stop shop includes representatives from several government departments, the chamber of commerce, a private bank, and the notary public. Also, a Saudi entrepreneur pays nothing for registering property, and it only required to be notarized and not linked to a cadaster, which could lead to less security [47]. The government has implemented large-scale public programs that are focused on providing professional and financial support for startups. There are many different government institutions mandated to support startup activity in Saudi Arabia directly. For example, the Loan Guarantee Program Kafalat [48]. The program issues bank guarantees to small and medium enterprises throughout the country.
Thus, one of the essential governmental institutions is the Saudi Public Investment Fund, which has joined forces with Japan's Softbank in order to create a new global tech investment fund. Saudi Arabia government has encouraged and bolstered youth to involve in starting small businesses. In 2007, the King Abdulaziz City for Science and Technology had launched an initiative the Badir Program for Technology Incubators [49]. Now, this program has five incubators spread across the cities of Riyadh, Jeddah, and Taif. The program aims to promote and enhance the culture of innovation and independent business amongst Saudi youth; it has served more than 200 startups since it launched. Their numbers are expected to increase soon [7].

Moreover, King Abdullah University of Science and Technology (KAUST) helps Saudi scientists and students, who are looking to spin out their inventions into new companies, and making their business idea a reality [50]. It offers training and mentorship to entrepreneurs both on and off campus. The university targets Saudi business' owners who are interested in adopting an entrepreneurial approach to business growth. KAUST supports entrepreneurs at all the process: ideation, launch, funding and beyond.

Also, it helps inventors to protect and commercialize their inventions. KAUST is supporting new ventures that have local or regional impacts and create jobs. Since entrepreneurship education contributes to building a culture of innovation and entrepreneurship, King Abdullah University of Science and Technology has the Entrepreneurship Center. It has an evolution program of the three-month-long, which helps to develop some of KAUST's first startups. Besides, there is another program of 
six months long and is mentor-led by a cadre of seasoned entrepreneurs and investors. The Jeddah Chamber of Commerce and Industry (JCCI) has started a business training program, which is entitled entrepreneurship education for young children [51]. The purpose of this program is spreading a culture of financial and commercial awareness among the younger generation and instill an entrepreneurial spirit in them from an early age. Also, it helps them to promote their ability for the implementation of future projects. Recently, forty young children aged between 10 and 15 years have participated in the program from different schools to learn the basics of business skills under the supervision of the JCCI. This program was prepared by the youth's consultation and community department at the King Abdulaziz University. Saudi Arabia's entrepreneurial ecosystem has been growing fast during the past seven years. Public and private sector got more involved in supporting the ecosystem. The entrepreneurial ecosystem improves the network and cooperation between the country cities and regions. However, the ecosystem has been implemented to be flexible and sustainable in order to bring various opportunities for startups. As a result, the country has started to have several rewarding industries for startups, including different industries such as healthcare and EdTech. For example; the EdTech industry, which is expected to grow by about $8 \%$ per year in Saudi Arabia [52].

\section{CONCLUSION}

Saudi Arabia is a rich country, a GDP $\$ 653.2$ billion, which enjoys high financial potential. The country Economic Development Phase is efficiency-driven [7]. Saudi Arabia population is 31.5 million in 2017 [7], more than half of them are below the age of 25 years [15]. Most of the youths in Saudi Arabia have graduated from prestigious universities in the world in various fields. Some of them are holding degrees in business, others in engineering, and many of them who are graduated with different degrees in different sciences majors. It is time to employ all these valuable resources and implement them into something that can improve the individual and society [15]. Entrepreneurship has the power to make a positive economic change while remaining profitable for both the people and the government. Saudi Arabia is taking extraordinary steps into the entrepreneurship world. Many researchers have tried to find a clear interrelationship between unemployment and entrepreneurship.

This paper is a contribution to continue searching and clear the ambiguities of this relationship. With all this high attention from researchers and economists about the relationship between entrepreneurship and unemployment, we suggest entrepreneurship to resolve the problem of unemployment in Saudi Arabia. The aim of this paper is investigating this relationship by analyzing the relationships between the components in Figure 1. As we see the Kingdome of Saudi Arabia (as a case study) works on to improve the strategies that can support to create an entrepreneurial culture and encourage the youth to involve in starting small businesses.

However, Saudi Arabia is still needed to invest in science and research as stated in Vision 2030 to continue developing the entrepreneurship ecosystem. Also, the government needs to foster the creation of entrepreneurial ecosystems in strategic locations through the analysis of the internal market distribution [7], and implement corrections to redistribute and facilitate new entrants, entrepreneurs, and enterprises. Lastly, our future research will continue following and evaluating the existing entrepreneurship ecosystem improvement phases and its impact on; lowering the rate of unemployment from $11.6 \%$ to $7 \%$; increasing enterprises' contribution to GDP from $20 \%$ to $35 \%$; and increasing women's participation in the workforce from $22 \%$ to $30 \%$, which are stated as part of Saudi Arabia's Commitments in the Government Vision 2030 [15].

\section{REFERENCES}

[1] A. Bokhari, "Entrepreneurship as a Solution to Youth Unemployment in the Kingdom of Saudi Arabia Entrepreneurship as a Solution to Youth Unemployment in the Kingdom of Saudi Arabia," Am. J. Sci. Res., no. 87, pp. 120-134, 2013.

[2] G. Packham, P. Jones, C. Miller, D. Pickernell, and B. Thomas, "Attitudes towards entrepreneurship education: A comparative analysis," Educ. + Train., 2010.

[3] M. Goethner, M. Obschonka, R. K. Silbereisen, and U. Cantner, "Scientists' transition to academic entrepreneurship: Economic and psychological determinants," J. Econ. Psychol., 2012.

[4] M. Jeraj and J. Pavlin, "Entrepreneurship As a Solution To the Unemployment Problem,” Škola Biznisa, vol. 2, no. January, pp. 89-97, 2010 .

[5] A. Roy, A. Martin, V. Stel, J. André, and B. David, "Does SelfEmployment reduce Unemployment?," Jena Econ. Res. Pap. No. 2007,089, 2007.

[6] N. Bosma and J. Levie, "Report Global Entrepreneurship Monitor 2009 Executive Report," 2009.

[7] GEM, "Kingdom of Saudi Arabia report 2017 -18, Global Entrepreneurship Monitor (GEM) survey," 2017.

[8] N. Meyer, "Creating an Entrepreneurial Culture Among Students Through Entrepreneurship Development Programmes (EDP)," Mediterr. J. Soc. Sci., 2014.

[9] R. Morris, "High-Impact Entrepreneurship Global Report Center for High-Impact Entrepreneurship at Endeavor," Glob. Entrep. Monit., p. 16, 2011.

[10] The World Bank, "How does the World Bank classify countries?" The World Bank, 2014.

[11] E. E. Okafor, "Development Crisis of Power Supply and Implications for Industrial Sector in Nigeria," Stud. Tribes Tribals, 2008

[12] M. Crum and Y. Chen, "Self-employment and subjective well-being: A multi-country analysis," Int. J. Entrep., vol. 19, no. January 2015, pp. 15 26, 2015.

[13] International Labour Office, "Global employment trends for youth 2013: A generation at risk," 2013.

[14] G. D. Bruton, D. J. Ketchen, and R. D. Ireland, "Entrepreneurship as a solution to poverty," J. Bus. Ventur., 2013.

[15] K. Salman, B. I. N. Abdulaziz, and A. L. Saud, "VISION 2030, Kingdom of Saudi Arabia," 2018.

[16] W. Bank, "World Development Indicators," https://data.worldbank.org/country/saudi-arabia, 2018.

[17] T. Blinova, S. Bylina, and V. Rusanovskiy, "Vocational Education in the System of Determinants of Reducing Youth Unemployment: Interregional Comparisons," Procedia - Soc. Behav. Sci., 2015.

[18] M. Kongolo, "Job creation versus job shedding and the role of SMEs in economic development,” African J. Bus. Manag., 2010.

[19] C. Murphy, "Saudi Arabia's Youth and the Kingdom's Future. Woodrow Wilson International Center for Scholars," Middle East Program. 
Available https//www. Wilson center. org/sites/default/files/Saudi\% 20Arabia\% E2, vol. 80, 2012.

[20] K. C. Awogbenle, A. Cyril, and Iwuamadi, "Youth unemployment: Entrepreneurship development programme as an intervention mechanism,” African J. Bus. Manag., vol. 4, no. 6, pp. 831-835, 2010.

[21] C. G. E. Salami, "Youth unemployment in Nigeria: A time for creative intervention,” Int. J. Bus. Mark. Manag., vol. 1, no. 2, pp. 18-26, 2013.

[22] A. R. Thurik, M. A. Carree, A. Van Stel, and D. B. Audretsch, "Does selfemployment reduce unemployment?,” J. Bus. Ventur., vol. 23, pp. 673$686,2008$.

[23] J. Zimmerman, Refining the definition of entrepreneurship. 2008.

[24] M. Szycher, The guide to entrepreneurship: How to create wealth for your company and stakeholders, CRC Press. 2014.

[25] D. B. Audretsch et al., "The Economics of Science and Technology," J. Technol. Transf., pp. 155-203, 2002.

[26] Khalifa et al., "Landscape Analysis: Fracking Technology.," in Infrastructure and Technology Management, 2018, pp. 19-44.

[27] M. Castells, The rise of the network society. Vol. 12. 2011.

[28] Guiso et al., "'People's opium? Religion and economic attitudes.," J. Monet. Econ., vol. 50.1, pp. 225-282, 2003.

[29] Gorodnichenko et al., "Culture, institutions and the wealth of nations.," Natl. Bur. Econ. Res., no. No. w16368., 2010

[30] Thierauf et al., "Management principles and practices: a contingency and questionnaire approach," John Wiley Sons, 1977.

[31] Puthanpura et al., "Assessing emerging automotive technologies for the future.," 2015 Portal. Int. Conf. Manag. Eng. Technol., 2015.

[32] J. Bronte-tinker, Z. Redd, and K. Moore, "Logic Models and Outcomes for Youth Entrepreneurship Programs," 2001.

[33] H. Etzkowitz, "Incubation of incubators: innovation as a triple helix of university-industry-government networks," Sci. Public Policy, vol. 29, no. 2, pp. $115-128,2002$.

[34] M. Cullen and P. Elizabeth, "Business Incubation in the Eastern Cape : A Case Study,” Int. J. Innov. Educ. Res., vol. 2, pp. 76-89, 2014.

[35] D. P. Begley, Thomas M. and Boyd, "Psychological Characteristics Associated with Performance in Entrepreneurial Firms and Smaller Businesses,” J. Bus. Ventur., vol. 2, no. 1, pp. 79-93, 1987.

[36] E. Faria, João Ricardo \& Cuestas, Juan Carlos \& Mourelle, "Entrepreneurship and unemployment: A nonlinear bidirectional causality?," Econ. Model., vol. 27(5), pp. 1282-1291, 2010.
[37] B. Administration and A. Ekiti, "Entrepreneurship Development: A Panacea for Unemployment Reduction in Nigeria," J. Emerg. Trends Econ. Manag. Sci., vol. 2, no. 4, pp. 251-256, 2011.

[38] C. Laffineur and S. D. Barbosa, "Active labor market programs ' effects on entrepreneurship and unemployment," Springer Sci. Media, pp. 889 918, 2017.

[39] R. Baptista and A. R. Thurik, "The relationship between entrepreneurship and unemployment: Is Portugal an outlier?," Technol. Forecast. Soc. Chang., vol. 74, pp. 75-89, 2007.

[40] A. Van Stel et al., "The Effect of Entrepreneurial Activity on National Economic Growth," Springer, pp. 311-321, 2005.

[41] Anokhin et al., "Entrepreneurship, innovation, and corruption," J. Bus. Ventur., no. 24.5, pp. 465-476, 2009.

[42] W. B. Group, "The Arab World Competitiveness Report 2018, World Economic Forum," 2018.

[43] K. M. Al Ammari, "FROM ENTREPRENEURIAL INTENTION TO ACTION: THE ROLE OF SELF-REGULATION AND CULTURAL VALUES, THE CASE OF SAUDI ARABIA, A thesis, Plymouth University," 2017.

[44] "Saudi Economic Woes Involve More Than Low Oil Price, The Epoch Times," 2016.

[45] "Saudi Approves Plan to Diversify Economy, The Wall Street Journal," 2016

[46] "Saudi Arabia, The Report 2016, Oxford Business Group, https://oxfordbusinessgroup.com/saudi-arabia-2016."

[47] "World Economic Forum 2010, The Global Competitiveness Report 20102011 Archived June 19, 2008, at the Wayback Machine., Geneva.".

[48] "KAFALAT, Guarantees for Loans to Small and Medium Enterprises: www.kafalat.com.lb/.".

[49] "The Badir Program for Technology Incubators: https://www.badir.com.sa/en/about-us/.".

[50] "King Abdullah University of Science and Technology: https://innovation.kaust.edu.sa/entrepreneurs/.".

[51] "Jeddah Chamber of Commerce and Industry in Saudi Arabia: https://www.chamber-commerce.net/dir/3722/Jeddah-Chamber-ofCommerce-and-Industry-in-Jeddah.".

[52] T. Assaf, "The Kingdom of Saudi Arabia: Status of entrepreneurship ecosystem," Wamda Res. Lab, no. June 2017. 